\title{
On Dokuzuncu Yüzyılda Kaleme Alınan İki Makâmât-ı Harîrî Tercümesi: Manastırlı Dâniş Ahmed Efendi ve Ahmed Hamdi Şirvânî̀nin Makâme-i Şîrâziyye'yi Tercümelerinin Mukayesesi
}

\section{Two Makâmât-ı Harîrî Translations in the 19 ${ }^{\text {th }}$ Century: Comparison of Manasturlı Dâniş Ahmed Efendi and Ahmed Hamdi Şirvânî's Makâme-i Şîrâziyye Translations}

\author{
Seda Aydın Kurt ${ }^{1}$ (1)
}

${ }^{1}$ Arş. Gör., İstinye Üniversitesi, Fen Edebiyat Fakültesi, Türk Dili ve Edebiyatı Bölümü, İstanbul, Türkiye

ORCID: S.A.K. 0000-0001-9202-9887

Sorumlu yazar/Corresponding author:

Seda Aydın Kurt,

İstinye Üniversitesi, Fen Edebiyat Fakültesi, Türk Dili ve Edebiyatı Bölümü, İstanbul, Türkiye E-mail: saydin@istinye.edu.tr

Başvuru/Submitted: 27.04.2020

Revizyon Talebi/Revision Requested: 07.05.2020 Son Revizyon/Last Revision Received: 10.05.2020 Kabul/Accepted: 11.05 .2020

\section{Atıf/Citation:}

Aydin Kurt, S. (2020). On dokuzuncu yüzyılda kaleme alınan iki Makâmât-ı Harîrî tercümesi:

Manastırlı Dâniş Ahmed Efendi ve Ahmed Hamdi Şirvânî'nin Makâme-i Şîrâziyye'yi tercümelerinin mukayesesi. TUDED 60(1), 57-70. https://doi.org/10.26650/TUDED2020-0024
ÖZET

Ebû Muhammed Kâsım bin Alî bin Muhammed el-Harîrı̂’nin 12. yüzyılda kaleme aldığı Makâmât'ı, makâme adı verilen elli kısa hikâyeden oluşan Arapça bir eserdir. Her makâmenin farklı bir şehirde geçtiği eserde, makâmelere o şehrin adı verilmiştir. Arap dilinin inceliklerinin secili bir üslûpla ortaya konulduğu eser, birçok dile tam veya kısmî olarak tercüme edilmiştir. Kaynaklarda, Makâmât-l Harîr̂̂̉nin Türk edebiyatında 17. yüzyıldan itibaren tercüme edildiği ifade edilmektedir. Fakat ulaşllabilen en eski tercüme, 19. yüzyılda Ahmed Hamdi Şirvânî tarafindan kaleme alınan Tercüme-i Makâmât adlı eserdir. Hicri 1290 (m.1873/1874) yılında Yahya Efendi Matbaası'nda basılan eser, iki cilt olup 450 sayfadır. Aynı yüzyılın sonunda bir diğer tercüme, Manastırlı Dâniş Ahmed Efendi tarafindan yazılmıştır. Hicri 1314 (m.1896/1897) yılında kaleme alınan eser, 915 sayfa olup basılmamıștır. Tek nüshası olup Makedonya Kütüphaneleri Türkçe Yazma Eserler Koleksiyonu'nda yer almaktadır. Bu makalede, Harîrî'nin Makâmât' inda yer alan 35. makâme olan Makâme-i Sirrâziyye'nin Ahmed Hamdi Şirvânî ve Manastırlı Dâniş Ahmed Efendi tarafından kaleme alınan tercümeleri ele alınacaktır. Söz konusu tercümeler; kullanılan metot, kelime kadrosu ve üslup bakımından mukayese edilecektir. Bu bağlamda çalıșmanın amacı, mukayese neticesinde ortaya çıkan benzer ve farklı yönleri incelemektir. Anahtar Kelimeler: Makâmât-l Harîrî, Makâmât, Harînî, Ahmed Hamdi Şirvânî, Manastırlı Dâniş Ahmed Efendi

\section{ABSTRACT}

Makâmât, written by Harîrî in the $12^{\text {th }}$ century, is an Arabic book consisting of fifty short stories called maqama. In the book where each maqama takes place in a different city, the maqama are named after that city. The book is written in a rhymed prose style that has been translated into many languages in full or in part. In the sources, even though it is stated that Makâmât-l Harîrî was translated into Turkish literature after the $17^{\text {th }}$ century, the oldest available translation is Tercüme-i Makâmât, written by Ahmed Hamdi Şirvânî in the $19^{\text {th }}$ century. The book was published by Yahya Efendi Press in h.1290(c.e.1873/1874) is two volumes and 450 pages. At the end of the same century, another translation was written by Manastırlı Dâniş Ahmed Efendi in h.1314(c.e.1896/1897). The book's single copy was in the Turkish Manuscripts Collection of Macedonian Libraries. In this article, the translations of Makâme-i Şîrâziyye, which was the $35^{\text {th }}$ maqama of Harîrî's Makâmât, written by Şirvânî and Dâniş Ahmed Efendi was used. These translations were compared in terms of method, vocabulary, and style. In this context, the aim of this study was to analyze the similarities and differences as a result of the comparison.

Keywords: Makâmât-ı Harîrî, Makâmât, Harîrî, Ahmed Hamdi Şirvânî, Manastırlı Dâniş Ahmed Efendi 


\section{EXTENDED ABSTRACT}

Ebû Muhammed Kâsım bin Alî bin Muhammed el-Harîrî popularly known as Harîrî was born in Basra in 1147. Although his masterpiece Makâmât consisted of fifty short stories called maqame, the book was not only prose but also a poem. In the maqames, the narrator, Haris bin Hemmâm, tells adventures of the story's fictional main character, Ebû Zeyd, who wears disguises to trap people. Thus, maqame is comparable to the genre of picaresque in Western literature. Harîrî’s Makâmât has been translated into several languages. Similarly, there are many translations of Makâmât in Turkish literature. One of them is Tercüme-i MakâmâtHarîr $\hat{\imath}$ which was written by Ahmed Hamdi Şirvâni in the $19^{\text {th }}$ century. He was born in Şirvân, Azerbaijan in h.1247(c.e.1831/1832). Likewise, a translation was written by Dâniş Ahmed Efendi at the end of same century. He was born in Manastır, Macedonia. In this article, the translations of Makâme-i Şîrâziyye, which was the $35^{\text {th }}$ maqama of Harîrî's Makâmât, was written by both Ahmed Hamdi Şirvânî and Dâniş Ahmed Efendi. These two translations were used for comparision.. Because Makâme-i Şîrâziyye was one of the shortest maqame, it was chosen for detailed research in this article. Ahmed Hamdi Şirvânî wrote his translation in h.1290(c.e.1873/1874), and it was published by Yahya Efendi Press. But, Manastırlı Dâniş Ahmed Efendi wrote by his own hand his translation in h.1314(c.e.1896/1897), and it was not published. When these two translations were examined based on Makâme-i Şî́âziyye, it drew attention to three different points. One of them was the translation method. In other words, it was how the translators translated the Makâme-i Şîrâziyye. While Ahmet Hamdi Şirvâni generally copied the words of the original text in his translation, Manastırlı Dâniş Ahmed Efendi explained each word one by one. Moreover, Manastırlı Dâniş Ahmed Efendi made grammatical examinations, and gave his own regional sayings in his translation, and then translated his text after from the title of "mahsûl-i 'ibâre" and commented after from the title of "ya "nî". But, this commentary did not change the original text. On the contrary, it provided more understanding of the original text. Another point was concerning the translations' vocabulary. Even though Manastırlı Dâniş Ahmed Efendi preferred mostly to use Turkish words, Ahmed Hamdi Şirvani chose constructions mainly consisting of Arabic and Persian words. The other point was the translation style. The styles of both translators were considerably different from each other. Manastırlı Dâniş Ahmed Efendi had a translation style composed of shorter sentences, plainer language, and clearer expressions. In contrast, Ahmed Hamdi Şirvânî’s style had substantially longer sentences, used Arabic and Persian constructions, and heavier language. Accordingly, it could be stated that Şirvânî used a classical prose style which is named as "münşiyâne". In conclusion, although the two translations seemed different in terms of method and purpose, they were actually similar. In other words, their aim was to translate the original text. Neither one changed the original text nor added their own interpretation. However similar their purpose, the way of realizing this goal were different. And so, it was encountered with the concept of style. Consequently, it could be said based on Makâme-i Şîrâziyye that Manastırlı Dâniş Ahmed Efendi and Ahmed Hamdi Şirvâni had the same purpose in their translations. However, they do not have a similar translation style. While Manastırlı Dâniş Ahmed Efendi 
used the classical commentary style, and wrote his translation for those willing to learn the Arabic language, Ahmed Hamdi Şirvânî used the "münşiyâne" style, and wrote his translation for the well educated and high level people to present them with a literal and artful translation. 


\section{GíRiș}

Lügatte "ayakta durmak" manasındaki "kıyâm" kökünden türemiş bir kelime olan "makâme", önceleri bir araya gelmiş insanların bulunduğu yer anlamına gelirken daha sonra bu toplanılan yerlerde söylenen sözler, "makâme” olarak adlandırılmıştır. Makâmeler, edebi bir tür olarak bir kahramanın başından geçen olayların bir râvî tarafından nakledildiği kısa hikayeler serisidir (Ayyıldız, 2003, s. 417). Makâmât da makâmenin çoğuludur. Makâmeler, farklı kılıklara girerek zekasıyla insanları kendine inandıran bir kahramanın maceralarını anlatması sebebiyle, Batı'da pikaresk adı verilen tür ile benzerlik göstermektedir (Esposito, 2013, s. 227). Arap edebiyatında makâme türünde ilk defa eser kaleme alan Câhız (ö. 869)'dır. Fakat makâme türü asıl şöhretini Harîrî’nin Makâmât’ı ile kazanmıştır (Ayyıldız, 2003, s. 417).

1054 yılında Basra'da doğan Ebû Muhammed Kâsım bin Alî bin Muhammed, dedesinin ipek ticareti ile meşgul olmasından dolayı el-Harîrî nisbesiyle anılmıştır (Kılıç, 1997, s. 191). Basra' da dönemin büyük hocalarından dersler almıştır (Furat, 1996, s. 299). 1122 yılında vefat eden Harîrî’nin eserlerinin çoğunluğu; Arap dili ve grameri üzerinedir (Kılıç, 1997, s. 191-192).

Harîrî'nin en meşhur eseri olan Makâmât, 50 makâmeden oluşan mensur bir eser olmasına rağmen her makâmede şiirlere de yer verilmiştir. Makâmeler secili bir üslûpla yazılmış ve her makâmede, Arap kültürünü yansıtan deyim ve atasözlerine yer verilmiştir. Hikâyelerde, dilencilik, zâhidlik, edebî konular, içtimaî, siyasi, ahlaki hususlar eleştirel bir dille ele alınmıştır (Gülle, 1995, s. 34). Makâmelerde hayalî bir kahraman olan Ebû Zeyd es-Serûcî, farklı kılıklara girip yalanlar söyleyerek herkesi kendine inandırır. Fakat gittiği her yerde karşısına Haris bin Hemmâm çıkıp onu ayıplarsa da Ebû Zeyd, ondan kurtularak başka bir şehre doğru yola çıkar. Olayların Haris bin Hemmâm tarafından anlatıldığg her makâmede aynı olay örgüsü tekrar etmektedir.

Harîrî'nin Makâmât'ı üzerine öncelikle Batılı âlimler çalışmıştır. İslam dünyasında esere otuz beş kadar şerh yazılmıştır. Eser, başta Türkçe olmak üzere Farsça, İngilizce, Fransızca, Almanca ve İbranice gibi dillere tam ve kısmî olarak tercüme edilmiştir (Kılıç, 2003, s. 415). Kaynaklarda Türk edebiyatında Makâmât üzerine 17. yüzyıldan itibaren çalışma yapıldığı ifade edilmiştir (Gülle, 1995, s. 48). ${ }^{1}$ Fakat ulaşılan en eski çalışma 19. yüzyılda Ahmed Hamdi Şirvânî tarafından kaleme alınmıştır.

Ahmed Hamdi Şirvânî, h. 1247(m. 1831/1832) yılında Şirvan'da doğmuştur. Babası, Şirvânî Abdullah Efendi'dir (CBOA, DH.SAİDd.4/116). İstanbul'a gelip tahsilini burada tamamladıktan sonra Mülga Teftiş ve Muayene Heyeti Reisliği’ne tayin olunmuş ilim ve irfan sahibi bir şahsiyettir. Üç dilde nazım ve nesirle yazma gücüne sahip olan Ahmed Hamdi Şirvânî, birçok eser kaleme almıştır. Bunlardan biri de Tercüme-i Makâmât-ı Harîrî̀ dir (Bursalı Mehmed Tâhir, t.y., s. 249). ${ }^{2}$

1 Makâmât-ı Harîrî üzerine Türk edebiyatında yapılan tercüme ve şerhler hakkında bkz. Aydın ve Özyıldırım, 2019, s. 1904.

2 Ahmed Hamdi Şirvânî hakkında ayrıntılı bilgi için torunu Fatma Rezan Hürmen tarafindan hazırlanan eserler için bkz. Ahmed Hamdi Şirvânî, 1995. Bkz. Biren, 1993. 
19. yüzyılın sonunda yaşayan bir âlim ve müderris olan Manastırlı Dâniş Ahmed Efendi de Makâmât-ı Harîrî' yi tercüme etmiştir. Dâniş Ahmed Efendi ${ }^{3}$, Manastır'da doğmuş; ilk eğitimini burada aldıktan sonra İstanbul'da tahsilini devam ettirmiştir (Cemil Paşa ve Esad Bey, 2008, s. 42). Tahsilini tamamlayıp Manastır'a müderris olarak dönen Dâniş Ahmed Efendi, burada eser yazarak hayatını devam ettirmiş ve h. 1316(m.1898/1899) yılında vefat etmiştir (Bursalı Mehmed Tâhir, t.y., s. 304). ${ }^{4}$

\section{Ahmed Hamdi Şirvânî’nin Tercüme-i Makâmât-ı Harîrî’si}

Ahmed Hamdi Şirvânî'nin Hicri 1290(m.1873/1874) yılında Yahya Efendi Matbaası'nda basılan Tercüme-i Makâmât-ı Harîrî'si, iki cilt olup 450 sayfadır. ${ }^{5}$ Eserin başında her makâme tercümesinin yer aldığı sayfayı gösteren bir fihrist bulunmaktadır. Fihristin ardından eserin baskısında yapılan yanlışları ve karşısında doğruları gösteren bir hatasavab cetveli verilmiştir. Daha sonra sırasıyla Kâmil Paşa, Ahmed Şetvân Efendi, Şâmî Mehmed Emîn el-Cündî, Hâce Mecîd Efendi, Ahmed Cevdet Paşa, Sâmî Paşa ve Râşid Efendi'nin Tercüme-i Makâmât-ı Harîrî için yazdıkları takrîzlere yer verilmiştir. Bundan sonra Tercüme-i Makâmât başlığı altında besmele ile Allah'a hamd edilip Hz. Peygamber'e salat ü selâm getirilmiştir. Ardından "ma'lūm ola ki” ifadesinden sonra Harîrî ve Makâmât adlı eserinden övgü ile bahsedilmiştir. Daha sonra mütercim, kendi adını zikrederek dönemin padişahı Sultan Abdülaziz Han'a dua ve senalarda bulunmuş ve Makâmât' 1 dibâcesinden itibaren tercümeye başlamıştır.

\section{Manastırlı Dâniş Ahmed Efendi'nin Tercüme-i Makâmât-ı Harîrî'si}

Tercüme-i Makâmât-ı Harîrî, Manastırı Dâniş Ahmed Efendi tarafından h. 1314(m.1896/1897) yılında kaleme alınmıştır. Eser, 915 sayfa olup basılmamıştır; tek nüshası müellif hattı olup Makedonya Kütüphaneleri Türkçe Yazma Eserler Kataloğu içinde "Oriantal Manuscript Turk” başlığı altında 923 numarada OMCT III/21 katalog numarasıyla bulunmaktadır (Aydemir ve Hayber, 2007, s. 439). Eserin başında bir fihrist yer almaktadır. Fihristten hemen sonra Makâmât-ı Edebiyye-i Harîriyye Şerhi Melâhât-i Dânişiyye başlı̆̆ı altında eserin Maarif Nezâret-i Celîlesi tarafından basılması için ruhsat-nâme çıktığı, yakın zamanda basılacağına karar verildiği ifade edilerek mütâlaa ve istinsâha heves-kâr olanlar için hatt-1 dest ile bir nüsha dahi yazılıp İshâkiyye Câmii Şerîfi Kütüphanesi’ne harice çıkmamak şartıyla vakfedilmiştir (OMCT III/21, s. II). Sonraki sayfada eserin mukaddimesi yer almıştır. Manastırlı Dâniş Ahmed Efendi, mukaddimesinde Allah'a hamd, Hz. Muhammed'e salat ü selâmdan sonra, Sultan

3 Sicill-i Osmânî Zeyli'nde Manastırlı Dâniş Ahmed Efendi'nin babasının adı Mehmed olarak geçmiştir (Cemil Paşa ve Esad Bey, 2008, s. 42). Dâniş Ahmed Efendi'nin eserlerinden biri olan Dest-âvîz-i Dâniş'in yazma nüshalarından birinde (Aydın, 2016, s. 20) ve çalışmanın konusu olan Tercüme-i Makâmât-ı Harîrî̀ de babasının adı, Sâlih olarak geçmiştir (OMCT III/21, s. II). Manastırlı Dâniş Ahmed Efendi'nin Makâmât-ı Harîrî adlı eseri üzerine yapılan bir doktora tez çalışması olup çalışma henüz tamamlanmadığı için yazmanın katalog numarası verilmiştir. Doktora tez çalışması ile ilgili ayrıntılı bilgi için bkz. Kurt, devam ediyor.

4 Dâniş Ahmed Efendi'nin hayatı ve eserleri hakkında ayrıntılı bilgi için bkz. Aydın, 2016, s. 20-23.

5 Ahmed Hamdi Şirvânî'nin eserinin yazma nüshasına kütüphanelerde rastlanmamıştır. 
Abdülhamid Han'a dua etmiş; ardından Makâmât-ı Harîrî̀ yi dîbâcesinden itibaren tercüme etmeye başlamıştır. Dâniş Ahmed Efendi, eserine kendi eliyle sayfa numarası vermiştir. Bu sayfa numaraları mukaddimeden başlamaktadır. ${ }^{6}$

\section{Makâme-i Şîrâziyye'den Hareketle Tercümelerin Mukâyesesi}

Çalışmada, Harîrî'nin Makâmât'ında yer alan 35. makâme olan Makâme-i Şîrâziyye’nin Ahmed Hamdi Şirvânî ve Manastırlı Dâniş Ahmed Efendi tarafindan kaleme alınan tercümeleri ele alınacaktır. ${ }^{7}$ Makâme-i Şîâziyye, diğer makâmeler gibi Haris bin Hemmâm'ın anlatımıyla başlar. Haris bin Hemmâm, Şirâz'da yürürken bir meclise uğrar. Bu meclis, seçkin kişilerden oluşur ve sohbet ederler. Sonra eski elbiseli, yaşlı bir zât meclise dahil olur, selam verir ve bir köşeye oturur. Meclistekiler onu kıyafetlerinden ötürü hakîr görürler. Yaşlı adam, fasîh ve belîğ bir şekilde nükteli sözler söyler ve oradaki herkesi etkiler. Sonra meclisten çıkmak için ayağa kalkar; fakat oradakiler onun eteğine yapışıp gitmesine izin vermezler, kendisine kim olduğunu sorarlar. Sonra yaşlı adam birden ağlamaya başlar. O sırada Haris bin Hemmâm, onun Ebû Zeyd olduğunu ve oradakileri kandıracağını anlar; fakat bu sırrı açığa vurmayarak sessiz kalır. Sonra Ebû Zeyd bir şiir okur ve meclistekilerden bir kızı olduğunu, onu evlendirmek için en az yüz altına ihtiyacı olduğunu; ama fakirlikten ona çeyiz yapamadığını söyleyerek yardım ister. Kendisi de yardım edene fasîh sözlerle medh ve dua edeceğini söyler. Oradaki herkes yardımda bulunur ve o da dualar eder. Sonra evinin yolunu tutar. Haris bin Hemmâm da onun arkasından gider. Ebû Zeyd, Haris bin Hemmâm'a şiir okur ve bu kızın üzüm kızı olduğunu, kendisinin onu bir gelin gibi kâseye koymak için hazırlandığını ifade eder. Sonra Ebû Zeyd, Haris bin Hemmâm'a veda ederek yoluna gider.

\section{Metot Bakımından Mukayese}

Ahmed Hamdi Şirvânî, Tercüme-i Makâmât-ı Harîrî adlı eserinde, tercüme ettiği Makâmât metnine yani kaynak metne yer vermeyip doğrudan tercümeye başlamıştır. Her makâme bu şekildedir. Tercüme sırasında bazı ibâre ve kelimelerin manalarını dipnotta vermiştir; bütün kelimelerin anlamları verilmemiştir. Dipnotta anlamı verilen kelime parantez içinde yazılmıştır. Kaynak metinde yer alan diyalog, monolog ve şiirler, aynen aktarılarak Arapça ve harekeli bir şekilde verilmiştir. Ahmed Hamdi Şirvânî, metni tercüme ederken genellikle kaynak metinde geçen kelimeleri aynen kullanmıştır. ${ }^{8}$

6 Dâniş Ahmed Efendi, eserini Ahmed Hamdi Şirvânî’den sonra yazmıştır. Ahmed Hamdi Şirvânî’nin eseri matbu ve iki eserin yazılmasının arasında yirmi yıldan fazla bir süre olmasına rağmen Dâniş Ahmed Efendi’nin eserinde Ahmed Hamdi Şirvânî'den söz etmemesi yoruma açık bir durumdur.

7 Bu makalede, Makâmât'ın 35. makâmesi Makâme-i Şîrâziyye'nin ele alınmasının sebebi, bu makâmenin hacim olarak diğer makâmelerin çoğundan daha kısa olmasıdır. Çünkü makâmeler uzun olduğunda, tercümeleri de çok uzun olabilmektedir. Çok uzun bir metnin her detayıyla incelenmesi hem bir makalenin sınırlarını aşacağı hem de bazı önemli noktaların gözden kaçmasına sebep olacağı için Makâmât'ın en kısa makâmelerinden biri tercih edilmiştir.

8 Ahmed Hamdi Şirvânî, tercümesinde kaynak metindeki kelimelerin çoğunluğunu, vezinlerini dahi bozmayarak olduğu gibi aktarmıştır. Tercüme faaliyetlerinde kaynak metindeki söz varlığının diğer dile olduğu gibi geçirilmesi, tercümenin anlaşılabilirliğinin yanında dilin yozlaşması sorununu da gündeme getirmiştir (Yazar, 2011, s. 224). 
Manastırlı Dâniş Ahmed Efendi'nin eseri hem bir tercüme hem de bir şerhtir. Manastırlı Dâniş Ahmed Efendi, eserinde kaynak metni cümlelere bölerek harekeli bir şekilde aynen vermiş ve her cümledeki harf-i cer, edat ve şahıs ekleri ve benzeri ibâreler hariç her bir kelimeye parantez içinde yer vererek anlamını tek tek açıklamıştır. Bu açıklama esnasında gramer izahlarına girişmiş; her kelimenin kök hâlini göstermeye gayret etmiştir. Bazen kelimelerin Farsça ve Türkçe karşılığını da veren Dâniş Ahmed Efendi, bazen de yaşadığı bölgenin yerel hayatı hakkında bilgi vermiştir. Sonrasında mahsûll-i 'ibâre diyerek bire bir çeviri yapmıştır. Bu çeviride kelime dizilişi bakımından metne sadık kalmış ve son olarak ya 'nî diyerek metni şerh etmiştir.'

Makâme-i Şirâziyye'nin ilk cümlelerinin kaynak metne de yer veren Manastırlı Dâniş Ahmed Efendi tarafından tercümesi şöyledir:

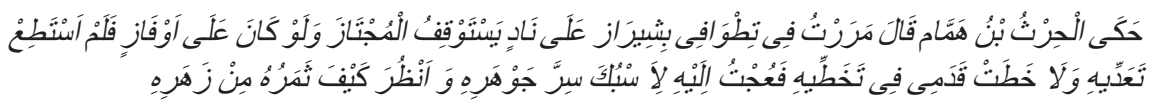

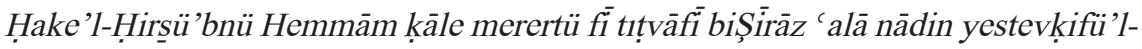
müctāze velev kāne 'alā evfāzin felem esteț' ta' addīhi velā hatet ḳademī fī tahatțîhi fe'uctü ileyhi liesbüke sirre cevherihi ve enzüre keyfe șemerühü min zeherihi

(17) نطو اف bir nesneniñ çevresini tolanmak, شررت bilād-1 Fāris'de (18)

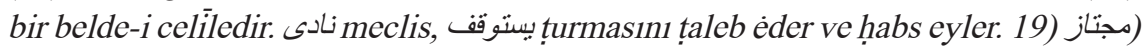

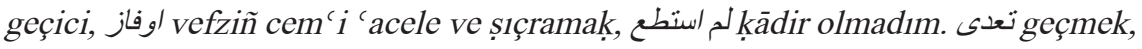

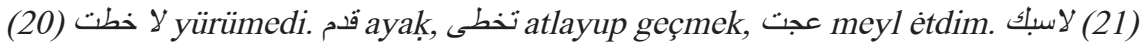

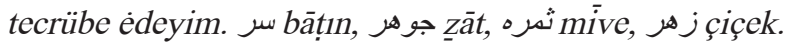

(22) Mahșūl-i 'ibāre: Haris bin Hemmām hikāye èdüp dèdi: Şīrāz’ñ çevresini țavāf ve deverānımda (23) bir meclise ug̉radım ki geçici kimseyi 'acele üzerine olsa bile tavakkuf ètdirir ve habs èder. Bu șüretde (24) o meclisi geçmege kādir olmadım ve atlayup geçmege ayaǵım yürümedi imdi mezbūr meclise meyl ètdim tā ki (25) ehliniñ bātınını tecrübe èdeyim ve çiçeginden mivesi ne keyfiyyetdedir bileyim ya'nī bātınları ẓāhir hāallerine [607] muvāfị mıdır añlayayım (OMCT III/21, s. 606-607).

Aynı cümlelerin Ahmed Hamdi Şirvânî tarafindan tercümesi şu şekildedir:

(15) Hāris bin Hemmām hikāyet èder ki ețāf ü eknāf ve meclāy u mețāf-1 Şīrāz-1 (16) behcet-ṭ̂āzı țavāfimda sür ' at ü evfāz üzere mārrīn ü müctāzı tevkịif èden (17) bir meclis-i dil-güşā ve nādì-i feraḥfezāya teșādüf ètdigimden bilā-ih̆tiyār tahutți

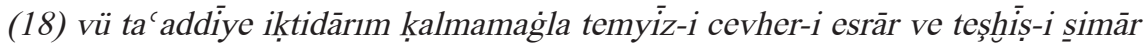
ü ezhār içün (19) ben dahi șaflarında cāy-gīr-i karār olduḳda gördüm ki (Ahmed Hamdi Şirvânî, 1290, s. 292).

9 Manastırlı Dâniş Ahmed Efendi’nin eserinde bir medrese hocası tavrıyla okuyucuya Arap dilini öğretmek amaciyla yaptığı gramatikal açıklamalar, bu eseri şerhe yaklaştırmıştır. Her ne kadar bu makâmede olmasa da diğer makâmelerin tercümesinde ifadeleri daha iyi açıklamak için tercümenin ya 'nì kısmından sonra fă 'ide, ihțār gibi başlıklar koyarak verdiği ek bilgiler de eserin bir şerh metni olarak ele alınmasını zorunlu kılmıştır. Nitekim tercüme ve şerh hem kavram hem de edebî bir faaliyet olarak iç içe geçmiş durumdadır (Yazar, 2011, s. 15). 
Ahmed Hamdi Şirvânî, kaynak metinde "Şirâz'ın çevresini dolanmak” anlamına gelen

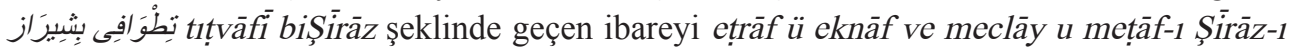
behcet-țrāzı țavāfimda şeklinde çevirmiştir. Buradan hareketle metne anlamını bozmayacak

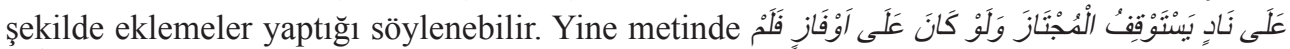

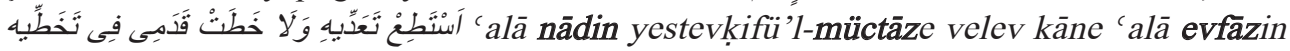

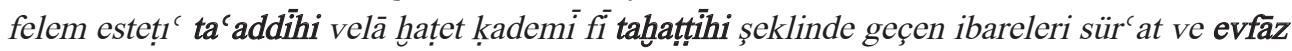
üzere mārrīn ü müctāzı tevḳif èden (17) bir meclis-i dil-güşā ve nādī-i ferah-fezāya teșādüf ètdigimden bilā-ihtiyār tahatți (18) vü ta'addìye olarak tercüme etmiştir. Verilen örneklerde görüldüğü üzere Şirvânî, genellikle atıf tamlamalarının bir kelimesini kaynak metinden Türkçeye tercüme etmeden olduğu gibi aktarmış ${ }^{10}$ bazı kelimeleri de tercümede olduğu gibi verip dipnotta açıklamıştır:

[293] ehl-i meclis țmreyn içün anı tahkịir ve izdirā (والمرء باصفريا) fikra-i meşhüresini (2) hâtırırlarında insā eyleyüp ' $\bar{u} d-1$ vücūdını makūle-i ahşāa u ahțābdan (3) zann ile bilā-iltifăt mütedā' $\bar{i}$ fașl-1 huțāb oldılar. Şahș-1 mezbūr ise bilā-ifāże-i (4) kelime vü ibāne-i simme sākit ü sāmit vücūh-1 cemā'ate nāzır iken cemā' at sebr-i karā ’ịh (5) ve imtihān-1 şā 'il ü rāciḥ içün istihrāc-1 defầ 'in ve istinsāâl-i kenā 'in eyledikde

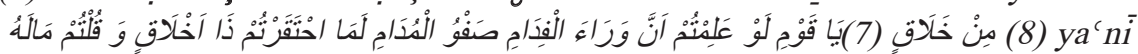
ey kavm verā-i fidāmında șafv-1 müdām oldığını teyaḳkun u ifhām ètmiş ola idiñiz (9) kisvesi jende olan pīr-i pejmürdeyi iḥtikār ve fażlını inkārla saña bizden nașīb (10) yoḳdur diyerek istișkāl ètmez idiñiz dèdikden șoñra yenābí ' i'l-edeb ve nüket-i müntehabdan (11) cāżib bedā' 'i' -i istiğrāb u 'aceb ve zevb-i zeheble kitābeti müstevcib olan zülāl-i muhāżarātı (12) tefcìr èdüp cālib-i dịkkat-i nevāẓır ve hāalib-i şevk-i huvāṭrdan șoñra müteheyyī-i 'azm ü irtị̂āl (13) ve müte 'ehhib-i seyr ü intikāl olduḳda cemā' at müte 'allık-1 dāmen ü zeyl ve māni`'i sereb-i seyli (14) olup dediler ki (وَ مُحِّكَ (15) ya'ni emāre-i 'ilmiñi irā 'e ve vebl-i fażlıñla bizi sikāye eyledikde ba'dezīn zāhir (16) ve bāṭn ya'ni sülāle ve mavṭ̂n-1 kedin ibāne eyle deyince șümūt-1 müfḥem ve süküt-1 mülzem gibi (17) sükūtla hayrān u nekrān oldukdan șoñra dilleri sūzān édinceye degin ref ${ }^{r}-1$ (18) șavtla nālān u giryān oldı rāvī dèr bu ādemden Ebū Zeyd'iñ şevb ü revb ve üslūb-1 (19) me 'lüf ile ḳașd u șavbını görünce sühūmet-i müheyyā ve sühūket-i reyyāsına im 'ān (20) u dikkat eyledikde Ebū Zeyd oldığını ikkān èdüp her ne kadar hịle-kārlıg $\dot{g}_{1}$ vāreste-i (21) şübhe vü gümān ise de yine dā'-i daḩì müstehcenü'l-beyān ketm olurcasına...

متداعى فصل خطاب birbirini feșāhat ve belāgate da'vet (23) ètmek,

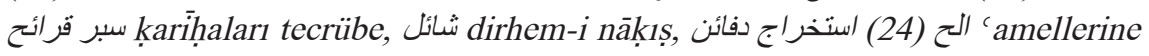

10 Ahmed Hamdi Şirvânî’nin kelimeleri çevirmeden doğrudan aktarmasının bir sebebi, kaynak metindeki sanatları gösterme endişesi olabilir. Nitekim tercüme ettiği eser, edebî sanatlarla süslenmiş secili bir üslûba sahiptir. Kendisi bir mütercim olarak bu incelikleri olduğu gibi aktarmayı tercih etmiş olabilir. Bir diğer sebep ise kelimelerin anlamının okur kitlesi tarafından bilindiğini düşünmesi olabilir. Bu da Şirvânı̂’nin okur kitlesinin kimlerden oluştuğu sorusunu akla getirir. Şirvânî’nin eserinin giriş kısmında hitap ettiği kitle ile ilgili bir ifade geçmemektedir. Ayrıntılı bilgi için bkz. Ahmed Hamdi Şirvânî, 1290, s. 2-3. 


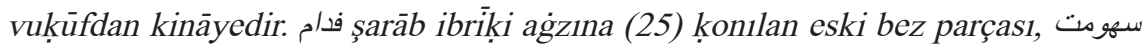

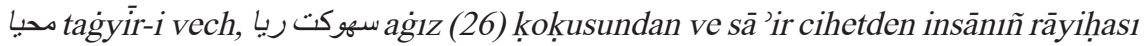
kerih olmak (Ahmed Hamdi Şirvânî, 1290, s. 293).

\section{1. Benzerlikler ve Farklılıklar}

Aynı yüzyılda aynı eseri tercüme eden iki mütercimin metodu, geleneksel olarak da adlandırılan klâsik şerh metodudur. ${ }^{11}$ Her iki mütercim de kaynak eseri, bir ekleme ve çıkarma yapmadan ve anlamını bozmadan tercüme etmiştir. Ahmed Hamdi Şirvânî, kaynak eseri herhangi bir açıklamaya başvurmaksızın, doğrudan tercüme etmiştir; eserine de "Tercüme-i Makâmât” ismini vermiştir. Manastırlı Dâniş Ahmed Efendi ise, kaynak eseri kelimelerine ayırıp gramer yapısını açıkladıktan sonra tercüme etmiş ve gerekli gördüğü yerde metin daha iyi anlaşılsın diye ek bilgiler vermiştir. Fakat bu bilgiler yorum niteliğinde olmayıp kaynak metnin anlamını bozmamış; aksine okurun kaynak metinle arasındaki zaman farkından doğan bilgi eksikliğini kapatmayı amaçlamıştır. Bu özellikler, Manastırlı Dâniş Ahmed Efendi’nin eserini tercüme olmanın yanında şerhe yaklaştırmıştır. Nitekim Manastırlı Dâniş Ahmed Efendi, eserine Makâmât-ı Edebiyye-i Harîriyye Şerhi Melâhât-i Dânişiyye adını vermiştir. ${ }^{12}$

\section{Kelime Kadrosu Bakımından Mukayese}

Manastırlı Dâniş Ahmed Efendi'nin eserinde kullandığı kelime kadrosu, Türkçe kelimelerden oluşmaktadır. Dâniş Ahmed Efendi, kelimelerin gramatikal olarak açıklandığı bölümde, bazen kendi yaşadığı Manastır bölgesinde o kelimenin karşılığını da vermiştir:

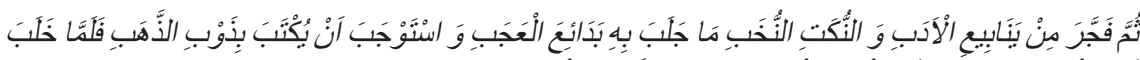

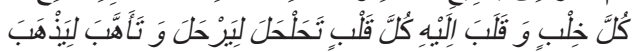

Sümme feccere min yenābī'i'l-edebi ve'n-nüketi'n-nuhebi mā celebe bihi bedā 'i'a'l'acebi ve'stevcebe en yüktebe bizevbi'z-Zूehebi felemmā halebe külle hilbin ve kalebe ileyhi külle kalbin tahalhale liyerhale ve te 'ehhebe liyezhebe

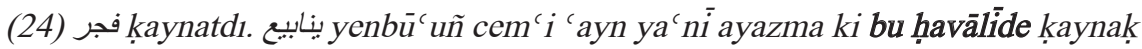
dèrler. ادب envā`-1 hațādan mābihi'l-iḥtirāz olan nesneyi bilmekden 'ibāretdir.

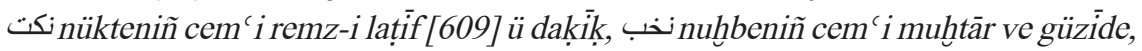

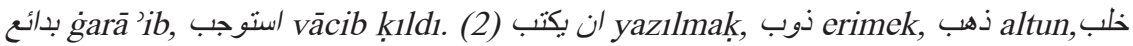

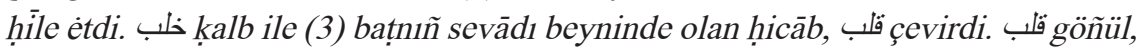

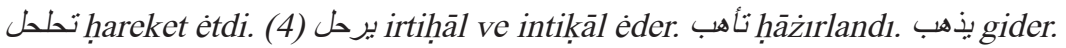

(5) Mah̆șūl-i 'ibāre: Bundan șoñra edeb ve güzíde ve müntehab nükteleriñ ayazmalarını kaynatdı ki anıñla 'aceb (6) garā 'ibini celb ètdi ve erinmiş altun ile

11 Ayrıntılı bilgi için bkz. Kılıç, 2007, s. 365.

12 Şerh metinleri, metot ve amaçlarına göre; edebî vurguyu ön plana çıkaranlar, tercüme ve dil öğretimi amacıyla yazılanlar ve tasavvufi arka planı vermek için kaleme alınanlar olarak tasnif edildiğinde bu makalede ele alınan iki metin de aynı amaç ve metot ile yazılmıştır. Kaynak metin, edebî vurgusu ön plana çıkarılarak veya tasavvufi arka planı verilerek "murâd şudur ki” denilip kastedilen şekliyle değil, olduğu gibi açıklanmıştır. İki metnin amacının da tercüme ve dil öğretimi kapsamına girdiği düşünülmektedir. 
yazılmasını vācib ḳıldı imdi vaḳtā ki her ḳalbiñ (7) hịcābına ḥile ètdi ve her bir göñli kendüye çevirdi irtihāal içün hareket ètdi ve gitmek (8) içün ḥāżırlandı(OMCT III/21, s. 608-609).

Verilen metinde görüldüğü gibi, mahsûl-i 'ibâre kısmında tamlama bulunmamaktadır; kelimeler de açıklama kısmında anlamlarının verildiği şekliyle veya daha basit hâliyle yer almıştır. Buradan hareketle, Manastırlı Dâniş Ahmed Efendi'nin eserini daha geniş kitlelere ulaştırmak amacıyla yazdığı, maksadının yalnızca kaynak eseri tercüme etmek değil aynı zamanda kaynak eserin dilini okuyucuya öğretmek olduğu sonucu çıkarılabilir.

Ahmed Hamdi Şirvânî’nin tercümesinde kullandığg kelime kadrosu Arapça ve Farsça iki veya üç kelimeli tamlamalardan oluşmaktadır. Eserde yalnızca zamir, fiil ve fiilimsiler Türkçedir, demek abartılı olsa da yanlış sayılmaz:

(21) Ma'nā-yı şi`r: Kemāl-i težellül ü iḥtikāāla keșretinden zahrı teșkîi ü pür-bār èden kabā 'ị (22) ü evzārımdan istiğfār eylerim ey kavm müddet-i tavīle hāne-i pederinde cālis ve vașf-1 [295] cemāli mümted ol endiye vü mecālis olan birçok 'ātik ü 'ā'isiñ muțālebe-i (2) ḳıșāṣ ve iddi' $\bar{a}-y 1$ diyesinden bì-pervā ve demini irāka ve katl olunduḳda żenbimi (3) ḳudretime havāle èderek nefs-i nā-bekār bu gayy u tuggyān ve temerrüd ü 'ișāndan fārig̀ ve bī-zār (4) olmayup katl-i ebkārda lecācet ve 1ṣrār eyledi ise de imdi zuhūr-1 kühūlet (5) ve nūr-1 şeyhūhhet māni` -i günāh u ma'șiyyet olup işrāk-1 tebāşīi-i lihyemden beri irāḳa-i dem-i (6) bākireye mübāşeret èdememişdir. İşte belā-yı żarūrete mübtelā bir sā 'il ü gedā (7) makūlesinden bulunmag̉la berāber dā 'ire-i terbiyemde müddet-i medìde neşV ü nemā birle yüzini (8) hevādan dahi mestūr u muģşā tutdığım bir bākire-i dilārā huṭbe-i gàniye vü muǵniye gibi (9) bu günlerde mahtūūbe ise de techízine yüz dirhemden akall pāre kifāyet ètmemesiyle (10) berāber bir dirheme bile istițā'atim olmayup mā' u gilādan arżım hāaliye ve sehāb (11) ü müzneden semā vü cevvim 'āriyedir ya'nì fakr-i hāal ve żarūret-i kāmile üzereyim imdi (12) sizde bir kerīm șāḥib-i ḥamiyyet var mıdır ki i' tâa-i derāhim-i mațlūbe ile o bākireyi (13) muǵnniye ve mutribe ile techīz ü tezvice mu'āvenet èderek alāyiş-i hemm ve levs-i gamımı (14) șābūn-1 žeheble gāāil ve ḳalbden efkār-1 mühzilesini müzā ’il olmag̀la 'ivażına rāyiḥa-i (15) țayyibesi münteşir olan ed iye vü eșniyeyi āhiz ü kābil ola. Rāví dèr cemā'atden (16) kefi cünbān ve 'örfi der-feyeżān olmayan bir kimse kalmayup vaḳtā ki merām ü bug̉yesini (17) tahșīl ve derāhim-i mi 'esini tekmīl edüp du'ā-i hayrla anlara $d u^{\prime} \bar{a}$ ve șenā ve teşmīr-i sāk (18) èderek inkifā ve insininā eyledikde hāne-perverde olup hengām-1 şebībesinde katline (19) mübāşeret ètmiş oldı $\dot{g}_{1}$ rebībesini ögrenmek içün 'akabinden şitābān oldukda (20) sür'at-1 ḳ1yāmım aña

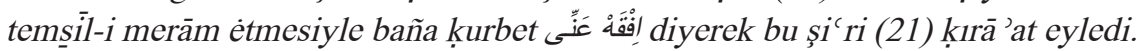

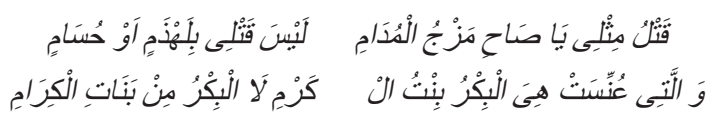


(24) غانبيه cemetden müli sebebiyle zevcini (25) nisve-i sÀéireden müstaànì úllan úadın, عرف iósÀn (Ahmed Hamdi Şirvânî, 1290, s. 294-295).

\subsection{Benzerlik ve Farklılıklar}

Aynı yüzyılda kaleme alınan iki tercümede kullanılan kelime kadrosu, her ne kadar Arapça, Farsça ve Türkçe kelimelerden oluşmak noktasında benzeşse de birbirinden farklıdır. Ahmed Hamdi Şirvânî, kaynak metnin kelime kadrosunu eserine çoğunlukla aynen nakletmiştir. Metnin bütünü göz önünde bulundurulunca kelimeler üzerinde çok az değişiklik yapıldığ 1 görülmektedir. Manastırlı Dâniş Ahmed Efendi ise eserinde Türkçe kelimeler kullanmaya gayret etmiştir. Neredeyse metnin hiçbir yerinde kaynak metinde yer alan kelimelere tercümesinde aynen yer vermemiştir.

\section{3. Üslûp Bakımından Mukayese}

Manastırlı Dâniş Ahmed Efendi, eserinin ilk sayfasında bu eserin basılması için iznin çıktığını; fakat müțāla'a ve istinsāḩa heveskār olanlar içün bir nüsha daha yazıldığını ifade etmiştir (OMCT III/21, s. II). Dâniş Ahmed Efendi'nin Yavuz Sultan Selîm Dîvân'ını şerh edip Dest-âvîz-i Dâniş adını verdiği bir başka eseri daha vardır. Dest-âvîz-i Dâniş'in ilk sayfasında Dâniş Ahmed Efendi, eserini Fārsìye heves-kār olanların faydalanması için kaleme aldığını söylemiştir (Aydın, 2016, s. 23; Terzi, 2016, s. 86). Kendisi bir medrese hocası olan Dâniş Ahmed Efendi'nin eserlerini heveskâr olanların faydalanması amacıyla yazdığı, üslûbunu da bu amaç doğrultusunda şekillendirdiği düşünülmektedir. Dest-âvîz-i Dâniş’ten bir beytin açıklaması şu şekildedir:

Riştehā-y1 cān-1 hod-rā sāhut Mecnūn sürh ü zerd

Tā berāy-1 hayme-i Leylā pelāsì naḳ̂s kerd

(12) rişte iplik, -hā edāt-1 cem', cān rūḥ-1 hayvānì, -rā edāt-1 (13) mef ùul, sāhut düzdi ve yapd1. Mecnūn Leylā'ya 'āşı̣ olan (14) Kayș-1 'Āmirî̀, sürh ḳırmızı, zerd șarı, tā edāt-1 ta' 'î̀, berāy- (15) bu daḩi ta' lìl içündür 'Arabìde lām-1 cārre gibi. hayme çadır, Leylī (16) Mecnün'uñ ma'şūkasınıñ ismi, pelās köhne kilim ve kecçe ve çul (17) ems̄āli nesnelere dènür. -i edāt-1 vahudet, naḳş bir nesneyi (18) iki yāhūu birḳaç renkler ile alaca eylemek ma'nāsına, kerd itdi.

(19) Mahsūül-i beyt: Mecnūn kendi cānı ipliklerini șarı ve ḳırmızı boyadı (20) tā ki Leylā'nıñ çadırı içün bir nemed ya' ni kecçe alaca eyledi, hulāṣa (21) Leylā'nıñ çadırı ki münakkkaşdır 'āşıkı olan Mecnūn kendi cānı [189] ipliklerinden tọuyup ve iştiyāḳdan kanlı yaşlarını aḳıdup anıñla boyamışdır (2) ve alaca eylemişdir (Aydın, 2016, s. 85).

Dâniş Ahmed Efendi'nin Makâme-i Şîrâziyye'de yer alan bir şiiri şerhi ise şöyledir:

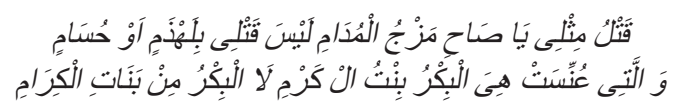


Katlü mișli yā șāḥi mezcü'l-müdāmi Leyse ḳatli bilehžemin ev hüsāmin Ve'lletí 'unniste hiye'l-bikrü bintü'l- Kermi la'l-bikrü min benāti'l-kirāmi

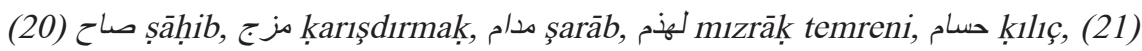

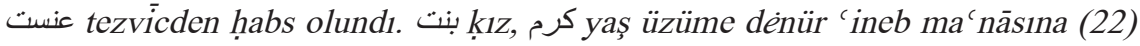
kurusuna zebīb derler. كرام kerimiñ cem'i nefāset ve 'izzet ve şeref șāḥibi.

(23) Mahsūūl-i nazm: Ey șāhị benim mișlimiñ ḳatli şarābı șu ile karışdırmaḳdır yohsa kılıç ile mızrāk (24) temreniyle katl degildir ve ol ḳı ki tezvīcden habs olundı yaş üzüm k̦ızıdır ya'ni şarābdır (25) kerímleriñ ḳılarından olan bikr degildir (OMCT III/21, s. 613).

Verilen iki metnin; kaynak metne yer verme, kelimeleri gramer izâhlarına da değinerek tek tek ele alma, şiirin düzenini bozmadan çeviri yapma gibi benzerliklerinden hareketle, Manastırlı Dâniş Ahmed Efendi'nin kendine has bir şerh üslûbu olduğu görülmüştür. Manastırlı Dâniş Ahmed Efendi'nin şerh ettiği şiirin Ahmed Hamdi Şirvânî tarafından tercümesi ise şu şekildedir:

Ma'nā-yı şi' r: Ey dost-1 'ālì-maḳām benim ems̄āl ve aḳrānımıñ ḳatli mezc-i müdām ve șu (4) ile şarābı mezc ü iltiyām olup yokssa rimāḥ u sihām ve seyf ü ḥusāmla ihlāk (5) u i`dām olmadı ġ1 gibi țūl-i maḳām-1 bākireden merāmım birçoḳ eyyām bint-i kermiñ (6) hānemde ārāmı olup yoksa benāt-1 kirāmdan bir bākire-i be-nām degildir (Ahmed Hamdi Şirvânî, 1290, s. 296).

Ahmed Hamdi Şirvânî’nin tercümesinden verilen örneğe bakılarak mütercimin kaynak eseri Türkçeye çevirirken kaynak metindeki ibareleri aynen aldığı ve bu makale içinde verilen diğer örnek metinlerde de olduğu gibi uzunluğu sebebiyle anlam karışıklığına yol açan cümleler kurduğu görülmektedir. Ahmed Hamdi Şirvânî’nin başka bir eserinde de tercüme esnasında aynı tavrı gösterdiği ifade edilmiştir (Erdoğan ve Çöklü, 2018, s. 44).

\subsection{Benzerlikler ve Farklılıklar}

Manastırlı Dâniş Ahmed Efendi ve Ahmed Hamdi Şirvânî'nin tercümelerinden hareketle üslûplarının çok farklı olduğu söylenebilir. Manastırlı Dâniş Ahmed Efendi'nin tercümesi daha kısa cümlelerden, açık ve anlaşılır ifadelerden oluşup dili sadedir. Fakat Ahmed Hamdi Şirvânî, daha uzun cümleli, Arapça ve Farsça kelimelerin ağırlıkta olduğu, tamlamaların yoğun olarak kullanıldığı klasik inşâ üslûbuna sahip olup dili de oldukça ağırdır.

\section{SONUÇ YERINE}

Bu makalede, Arap dili ve edebiyatının en önemli eserlerinden olan Makâmât-ı Harîrı̂̀ nin 35. makâmesi olan Makâme-i Şirâziyye'nin aynı yüzyılda kaleme alınan iki tercümesi; metot, kelime kadrosu ve üslûp bakımından mukayese edilerek benzer ve farklı yönler ortaya konulmuştur. Çalışmadan hareketle ortaya çıkan sonuçlar şu şekildedir: 
1. Her iki tercüme, metot ve amaç bakımından farklı görünüyorsa da aynıdır. İkisinde de amaç, metni tercüme etmektir; metni olduğundan farklı anlam zeminlerine oturtup yorumlamak değildir. Her iki metin de kaynak metne sadık kalmıştır.

2. Her iki tercümede amaç farklı olmasa da bu amacı gerçekleştirme tarzı farklıdır. Bu da karşımıza üslûp kavramını çıkarır. Bir mütercimin dilinin ağır veya sade olması, cümlelerinin uzun veya kısa olması, Arapça, Farsça veya Türkçe kelimeleri kullanması yahut kullanmaması, tamlamalara yer vermesi veya vermemesi onun tercihinin bir sonucudur ve tüm bunlar onun üslûbunu belirlemektedir. Dâniş Ahmed Efendi, üslûbunu eserini faydalansınlar diye yazdığı okur kitlesine göre şekillendirmiştir. Aynı şekilde Ahmed Hamdi Şirvânî, iyi eğitimli okur kitlesine münşiyâne bir üslûpla kaleme aldığı edebî ve sanatlı bir tercüme sunmuştur. Nitekim üst düzey şahsiyetlerin esere takrîz yazmaları, eserin okur kitlesinin bu şahsiyetlerden oluştuğu ihtimalini düşündürüyorsa da kaynaklarda henüz böyle bir ifadeye rastlanmadığı için bu duruma ihtiyatla yaklaşılmalıdır.

Hakem Değerlendirmesi: Dış bağımsız.

Çıkar Çatışması: Yazar çıkar çatışması bildirmemiştir.

Finansal Destek: TÜBİTAK 2211/A yurt içi genel doktora programı bursiyeriyim.

Peer-review: Externally peer-reviewed.

Conflict of Interest: The author has no conflict of interest to declare.

Grant Support: TÜBİTAK 2211 / A domestic general PhD program fellow..

\section{KAYNAKÇA/REFERENCES}

Ahmed Hamdi Şirvânî. (1290). Terceme-i makâmât-ı harîrî. İstanbul: Yahya Efendi Matbaası.

Ahmed Hamdi Şirvânî. (1995). Seyahatname (Hindistan, Svat ve Afganistan) (Haz. F. R. Hürmen). İstanbul: Arma Yayınları.

Aydemir, Y. ve Hayber, A. (2007). Makedonya kütüphaneleri Türkçe yazma eserler kataloğu. Ankara: TİKA Yayınları.

Aydın, S. (2016). Destâvîz-i Dâniş (Yavuz Sultan Selîm Dîvânı 'nın şerhi) tenkitli metin ve inceleme (S. 180366). (Yayımlanmamış Yüksek Lisans Tezi). İstanbul Üniversitesi Sosyal Bilimler Enstitüsü, İstanbul.

Aydın, S., Özyıldırım, A. E. (2019). Manastırlı Dâniş Ahmed Efendi’nin Makâmât-1 Harîrî Tercüme ve Şerhi. VI. Ylldız Uluslararası Sosyal Bilimler Kongresi Tam Metin Bildiri Kitabı içinde (s. 1902-1911). İstanbul: Y1ldız Teknik Üniversitesi Matbaası. ISBN: 978-605-031-548-6

Ayyıldız, E. (2003). Makâme. Íslam ansiklopedisi (C. 27, s. 417-419). Ankara: Türkiye Diyanet Vakfi Yayınlar1.

Biren, T. H. (1993). II. Abdülhamid, meşrutiyet ve mütareke devri hatıraları. (Haz. F. R. Hürmen). İstanbul: Arma Yayınları.

Bursalı Mehmet Tâhir Efendi. (t.y). Osmanlı müellifleri (C.1). (Haz. F. Yavuz ve İ. Özen). İstanbul: Meral Yayınlar1. 
Cemil Paşa ve Esad Bey. (2008). Sicill-i Osmanî Zeyli. (Haz. Ö. Tok). Ankara: Türk Tarih Kurumu Yayınları. Cumhurbaşkanlığı Osmanlı Arşivleri (CBOA), DH.SAİDd.4/116.

Erdoğan, M. ve Çöklü, R. (2018). Ahmed Hamdi Şirvânî ve Türkçe muhtasar usûl-i fikıh adlı eseri ile ilgili bir değerlendirme. İhya Uluslararası İslam Araşstımaları Dergisi, 4(1), 27-47. ISSN: 2149-2344

Esposito, J. L. (2013). Oxford İslam sözlü̈̆̈̈̈. (Çev. Nurullah Koltaş). İstanbul: Ayrıntı Yayınları.

Furat, A. S. (1996). Arap edebiyâtı tarihi ı (başlangıçtan XVI. asra kadar). İstanbul: İstanbul Üniversitesi Edebiyat Fakültesi Yayınları.

Gülle, S. (1995). el-Harîrî hayatı, Arap dil ve edebiyatına dair çalışmaları. (Yayımlanmamış Doktora Tezi). İstanbul Üniversitesi Sosyal Bilimler Enstitüsü, İstanbul.

Kılıç, A. (2007)Dağılmış İncileri Toplamak: Şerh Tasnifi Denemesi. Prof. Dr. Abdülkadir Karahan Anısına I. Uluslararası Klâsik Türk Edebiyatı Sempozyumu içinde (s. 363-369). İstanbul: İstanbul Büyükşehir Belediyesi.

Kılıç, H. (1997). Harîrî. İslam ansiklopedisi (C. 16, s. 191-192). İstanbul: Türkiye Diyanet Vakfı Yayınları.

Kılıç, H. (2003). Makâmât. İslam ansiklopedisi (C. 27, s. 414-415). Ankara:Türkiye Diyanet Vakfi Yayınları.

Oriental Manuscript Turk (OMCT) III/21.

Terzi, B. (2016). Destâvîz-i Dâniş (Yavuz Sultan Selîm Dîvânı'nın şerhi) tenkitli metin ve inceleme (S. I-180), (Yayımlanmamış Yüksek Lisans Tezi). İstanbul Üniversitesi Sosyal Bilimler Enstitüsü, İstanbul.

Yazar, S. (2011). Anadolu sahası klâsik Türk edebiyatında tercüme ve şerh geleneği. (Yayımlanmamış Doktora Tezi). İstanbul Üniversitesi Sosyal Bilimler Enstitüsü, İstanbul. 